\title{
EFEK BAKTERI PELARUT FOSFAT TERHADAP PERTUMBUHAN ASPERGILLUS FLAVUS PADA PERKECAMBAHAN KACANG TANAH
}

\author{
Sholeh Avivi', Ida Sugeng Suyani² \& Sugeng Winarso ${ }^{1}$
}

\begin{abstract}
Effect of phosphate solubilizing microorganism to Aspergillus flavus development on peanut germination. Phosphate solubilizing microorganisms (PSM) are microorganisms which could increase the available $\mathrm{P}$ in plant media. The aim of this research is to determine the effect of PSM on A. flavus growth, and to identify it's effects on the growth dynamics of A. flavus as long as the peanut germination. The research were conducted in the Laboratory of Plant Diseases Department, Faculty of Agriculture, University of Jember, from August 2005 to May 2006 and divided in 2 stages: in vitro and germination stage. Base on in-vitro stage we concluded that Bacillus subtilis strain SK had better inhibition toward the growth of A. flavus than Pseudomonas fluorescent strain GM. B. subtilis strain SK could inhibit A. flavus as much as $74 \%$, whereas $P$. fluorescent strain GM was only reached 60\% compared to control. Base on the germination stage, $B$. subtilis in the desiccator supernatant (BsDS) could increase the dry weight of root up to $24.1 \mathrm{~g}$ better than P. fluorescens strain GM and control. We also found that $B$. subtilis strain SK was more effective to change the availability of $\mathrm{P}$ on plant media.
\end{abstract}

Key words: $B$. subtilis, P. fluorescens, A. flavus, peanut

\section{PENDAHULUAN}

Aspergillus flavus dan Aspergillus parasiticus merupakan jamur penghasil senyawa racun yang disebut aflatoksin. Kedua jamur ini pertama kali ditemukan di Inggris tahun 1960. Toksin ini berbahaya dan menyerang sistem imun tubuh manusia dan mekanisme kerja hati manusia, mamalia, maupun unggas sehingga menjadi faktor penyebab kanker hati (Adisarwanto, 2000; Cotty \& Jaime-Garcia, 2007). Sebanyak 58\% kejadian tumor dan kanker liver (hepatitis carcinoma) telah terdeteksi disebabkan oleh aflatoksin (Bryden, 1999; Sudjadi et al., 1999; Guzmán de Peña, 2007). Selain itu, aflatoksin pada hewan juga memicu keguguran, menurunkan bobot tubuh, menyebabkan kanker hati dan haemmorage (pembengkakan otot) (Guzmán de Peña, 2007).

Di Indonesia, infeksi A. flavus pada pertanaman kacang tanah di lapang, benih di penyimpanan, benih di pasaran dan biji konsumsi terjadi dengan tingkat serangan sekitar 60-80\% dengan kandungan aflatoksin 40-4100 ppm. Sedangkan kandungan aflatoksin pada kacang tanah siap saji yang beredar di supermarket dan pasarpasar lokal mencapai 1000 ppm (Sudjadi et al., 1999). Kadar sebesar itu jauh melebihi kadar yang diperkenankan untuk konsumsi di Australia yaitu $\leq 15$ ppb (Hansen \& Norman, 1999).

Keberadaan A. flavus pada benih merugikan, karena dapat mengakibatkan penurunan daya kecambah biji, perubahan warna embrio atau seluruh biji, mengakibatkan kenaikan kandungan asam lemak bebas dan perubahan berat biji (Supartini, 1997; Asis et al., 2005). Jamur ini juga dapat menguraikan trigliserida menjadi asam lemak bebas dan gliserol yang mempunyai bau dan rasa tidak enak yang sering disebut tengik (Supartini, 1997).

Mikroba pelarut P (MPP) dapat dimanfaatkan sebagai biokatalisator di dalam tanah, untuk meningkatkan ketersediaan $P$ tanah. Pada saat aplikasi di tanah yang tidak steril, MPP harus mampu berkompetisi dengan mikroba indigineous tanah tersebut. Selain itu mikroba tanah dapat pula menjadi agens biokontrol beberapa patogen tanaman.

Untuk menguji apakah MPP dapat pula berfungsi sebagai agens biokontrol patogen tanaman maka perlu dilakukan uji antagonistik dengan patogen tanaman. Berdasarkan masalah di atas maka perlu dilakukan uji antagonistik terhadap Aspergillus tersebut secara in vitro dan in vivo di laboratorium. Pada penelitian ini

\footnotetext{
${ }^{1}$ Jurusan Agroteknologi, Fakultas Pertanian, Universitas Jember, Jl. Kalimantan 23 Jember 68121. E-mail: avi_vi@yahoo.com

${ }^{2}$ Jurusan Agroteknologi, Fakultas Pertanian, Universitas Binamarga Probolinggo
} 
MPP yang digunakan adalah bakteri pelarut fosfat (BPF) dari genera Pseudomonas dan Bacillus. Menurut Rodriguez \& Fraga (1999), Rhizobacteria dari genera Pseudomonas, Bacillus dan Rhizobium digolongkan sebagai BPF yang punya kemampuan tinggi dalam melarutkan fosfat dalam media tanam.

Penggunaan strain BPF yang antagonis terhadap Aspergillus di Indonesia belum pernah dilakukan. Padahal BPF diketahui menghasilkan antibiotik yang mampu menghambat pertumbuhan jamur (Rao, 1994; Shweta et al., 2008).

Penelitian ini ditujukan untuk melihat efek dari pemberian BPF terhadap dinamika pertumbuhan Aspergillus pada kacang tanah di laboratorium, guna menekan serangan Aspergillus yang pada akhirnya diharapkan dapat menekan kadar kontaminasi aflatoksin, serta mampu meningkatkan ketersediaan fosfat tanah bagi tanaman.

\section{METODE PENELITIAN}

Penelitian dilaksanakan pada bulan Agustus 2005 sampai April 2006, di Laboratorium Penyakit Jurusan Hama Penyakit Tumbuhan, Fakultas Pertanian, Universitas Jember. Percobaan yang dilakukan pada penelitian ini ada dua tahap yaitu: (1) Uji antagonistik BPF P. fluorescens strain GM dan B. subtilis strain $S K$ terhadap A. flavus secara invitro; (2) $\mathrm{Uji}$ penghambatan A. flavus oleh BPF pada fase perkecambahan benih yang ditanam secara hidroponik.

\section{Uji Antagonistik BPF P. fluorescens strain GM dan} B. subtilis strain SK terhadap A. flavus secara In Vitro. Uji ini dilakukan untuk mengetahui daya hambat BPF terhadap pertumbuhan dan perkembangan $A$. flavus dalam media agar PDA. Uji dilakukan dengan cara meletakkan BPF di tengah media pada posisi satu titik (a) dan A. flavus pada posisi 4 titik (b) Sebagai kontrol digunakan hanya $A$. flavus yang diletakkan pada satu titik (a) (Gambar 1). Uji juga dilakukan dengan cara meletakkan BPF dan A. flavus dalam satu petridish dalam posisi masing-masing hanya satu titik.

Persentase penghambatan pertumbuhan jamur A. flavus dihitung berdasarkan rumus :

$$
I=\frac{d_{1}-d_{2}}{d_{1}} \times 100 \%
$$

dimana, $\mathrm{I}=$ persentase penghambatan pertumbuhan; $\mathrm{d}_{1}=$ diameter koloni A. flavus kontrol; $\mathrm{d}_{2}=$ diameter koloni A. flavus perlakuan. Semua pengujian diulang 3 kali. Pengamatan dilakukan hingga hari ke-14 yang meliputi zona penghambatan BPF terhadap A. flavus. Kriteria antagonis ditentukan apabila salah satu isolat dapat menekan pertumbuhan A. flavus. Sedangkan apabila tidak terjadi zona penghambatan berarti dianggap BPF tidak mempu menghambat pertumbuhan A. flavus.

Uji Penghambatan Aspergillus oleh BPF pada Fase Perkecambahan Kacang Tanah yang Ditanam secara Hidroponik. Pada tahap ini benih kacang tanah dikecambahkan dengan dua metode yaitu dengan dikecambahkan dalam kertas merang, digulung dan didirikan dalam plastik (UKDDP) dan dikecambahkan dalam selang plastik dalam desikator (Gambar 2).

Rancangan percobaan, rancangan lingkungan acak lengkap (RAL) dengan 3 faktor yaitu (A) Jenis BPF; (B) Metode Perkecambahan dan Cara Pemberian BPF; dan (C) Macam Larutan yang ditambahkan pada media tanam. Uji Duncan dilakukan apabila uji F pada perlakuan menunjukkan beda nyata.

Rincian taraf perlakuan pada masing-masing faktor adalah sebagai berikut: A. Jenis BPF, terdiri dari 3 perlakuan: (1) $\mathrm{K}=$ Kontrol (hanya diinokulasi dengan A. flavus); (2) Bs = diinokulasi dengan $B$. subtilis strain $S K$ dan A. flavus; (3) $\mathrm{Pf}=$ diinokulasi dengan $P$. fluorescens dan A. flavus. Inokulasi $A$. flavus dilakukan setelah benih tanaman berumur 5 hari dengan spora $A$. flavus yang ditumbuhkan pada media PDA $\left(10^{9} \mathrm{CF} \mathrm{ml}^{-1}\right)$. B. Metode Perkecambahan dan Cara Pemberian BPF terdiri dari 2 perlakuan yaitu: (1) $\mathrm{KL}=$ Kertas merang langsung, benih dikecambahkan dengan metode UKDDP dan diinokulasi BPF $\left(10^{9} \mathrm{CFU} \mathrm{ml}{ }^{-1}\right)$ dilakukan langsung saat tanam (BPF ditumbuhkan pada media nutrient broth (NB) cair over night selama 20 jam); (2) DS = Desikator Supernatan, benih dikecambahkan pada desikator dengan penambahan supernatan pada media. BPF ditumbuhkan pada media King's B cair over night selama 20 jam. Pada akhir inkubasi kultur disentrifugasi dengan 7500 rpm pada suhu $25^{\circ} \mathrm{C}$ selama 20 menit. Supernatannya digunakan sebagai bahan yang ditambahkan pada media tumbuh dalam desikator. C. Macam Larutan yang ditambahkan pada media tanam terdiri dari 2 perlakuan yaitu Aqudes (A) dan Larutan Hoagland (H). 


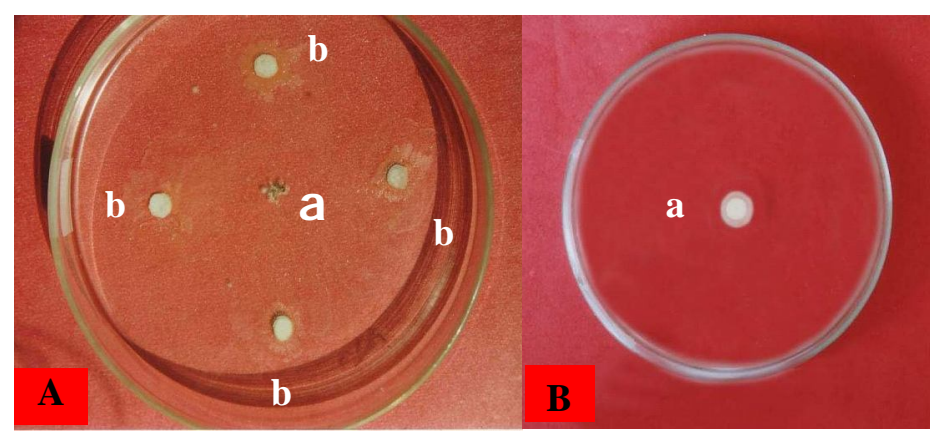

Gambar 1. Uji Antagonis BPF dengan A. flavus secara in vitro pada media PDA. $\mathrm{A}=$ Perlakuan; $\mathrm{B}=$ Kontrol; $\mathrm{a}=$ Jamur A. flavus; $\mathrm{b}=$ Bakteri Pelarut Fosfat

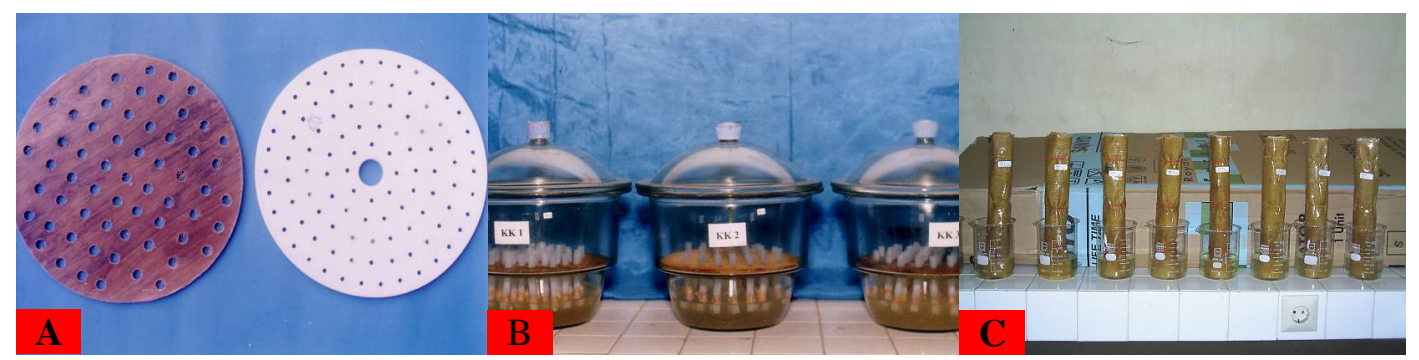

Gambar 2. Sistem kultivasi (kondisi aseptik) tanaman kacang tanah; (A) Lubang tempat selang untuk perkecambahan kacang tanah; (B) Perkecambahan kacang tanah setelah ditransfer pada desikator yang mengandung $1000 \mathrm{ml}$ larutan Hoagland; (C) Perkecambahan pada kertas merang

Pengamatan parameter pada tahap ini dilakukan hingga tanaman berumur 14 HSI (hari setelah diinokulasi dengan BPF), meliputi: (a) Persentase benih tidak tumbuh dan terserang penyakit sebelum diinokulasi dengan A. flavus, dengan cara menghitung benih yang busuk, terserang penyakit dan tidak tumbuh, (b) Persentase kejadian penyakit setelah tumbuh, (c) Berat basah dan kering akar, ditimbang sebelum dan sesudah dioven pada suhu $75^{\circ} \mathrm{C}$ selama 3 hari, (d) Total panjang akar, diukur dari pangkal batang sampai ujung akar, (e) Fosfat total terlarut pada media dianalisa dengan metode Olsen (Maxwell, 1968).

\section{HASIL DAN PEMBAHASAN}

Uji Antagonistik BPF P. fluorescens strain GM dan B. subtilis strain SK terhadap A. flavus secara In Vitro. Menurut Sastrahidayat (1987), BPF dapat bersifat antagonis terhadap A. flavus, karena BPF dapat mengeluarkan antibiotik yang dapat menghambat pertumbuhan A. flavus. Sementara A. flavus juga mengeluarkan antibiotik yang dapat menghambat pertumbuhan bakteri. Hasil yang sama juga diperoleh dari penelitian ini. Secara in vitro, B. subtilis strain $S K$ dan $P$. fluorescens dapat menghambat pertumbuhan A. flavus (Gambar 3).

Pada perlakuan kontrol, A. flavus tumbuh dengan cepat memenuhi cawan petri karena tidak ada mikroorganisme yang menghambat, namun pada perlakuan A. flavus vs B. subtilis strain SK (BsAf) pertumbuhan A. flavus sangat lambat, begitu pula pada perlakuan A. flavus vs $P$. fluorescens strain GM (PfAf) (Gambar 3). Pertumbuhan A. flavus lebih lambat pada perlakuan A. flavus vs B. subtilis strain $S K$ (BsAf) dibandingkan dengan perlakuan A. flavus vs $P$. fluorescens strain GM (PfAf). Pertumbuhan bakteri baik B. subtilis strain SK maupun P. flourescens mulai nampak pada $1 \mathrm{HSI}$, sedangkan pertumbuhan A. flavus mulai nampak pada 2 HSI. Pada 14 HSI, diameter pertumbuhan A. flavus kontrol mencapai 33,2 mm, sedangkan pada perlakuan BsAf mencapai $8,5 \mathrm{~mm}$ dan PfAf mencapai 13,3 mm (Gambar 4). 


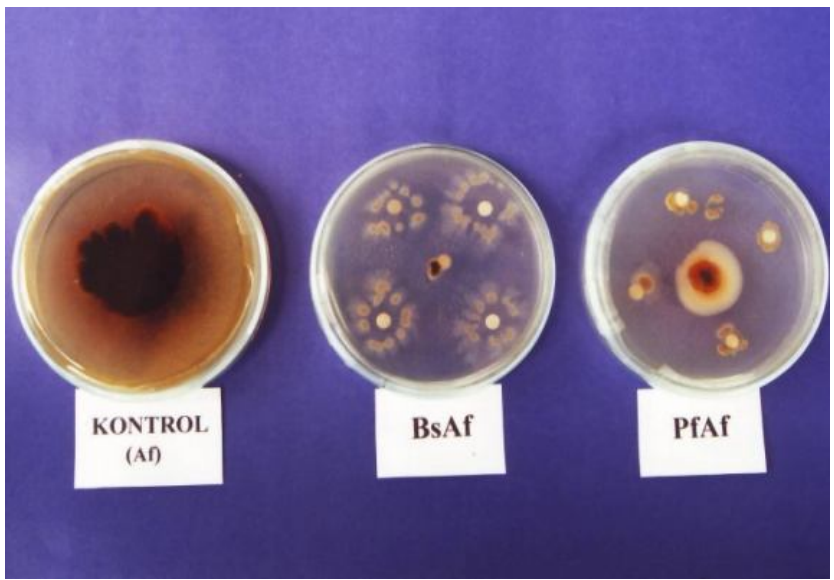

Gambar 3. Pertumbuhan A. flavus pada media PDA pada 14 HSI

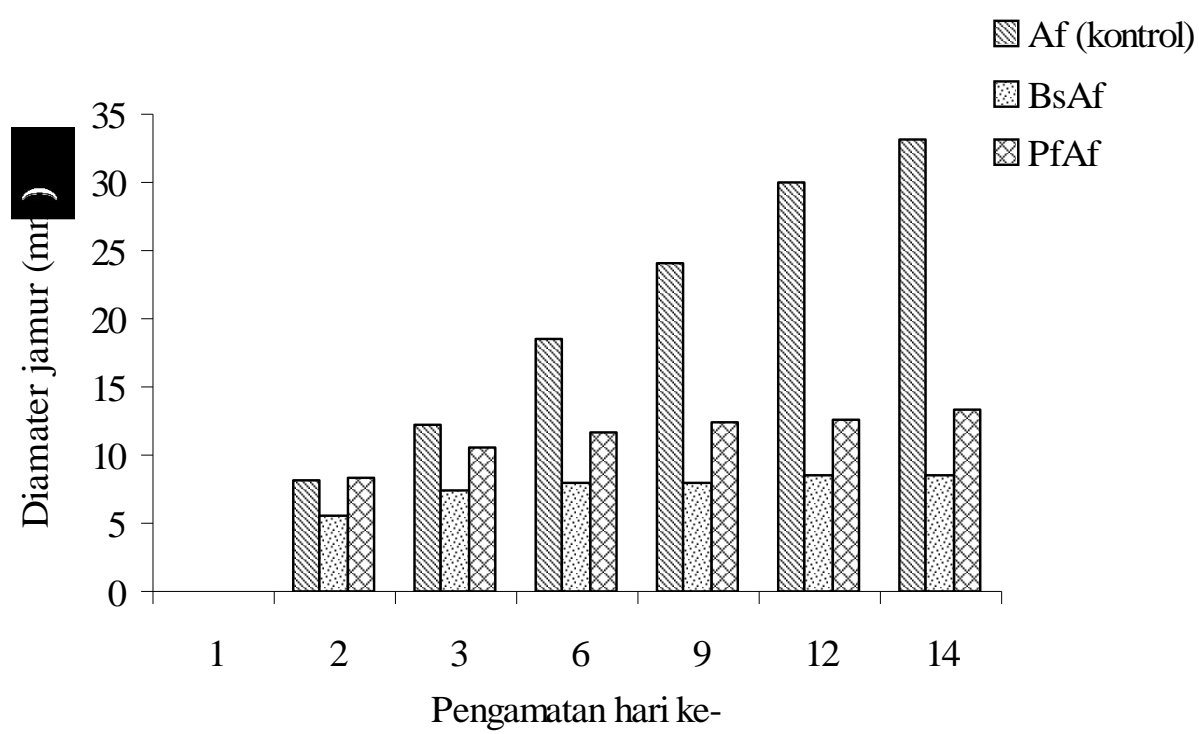

Gambar 4. Diameter pertumbuhan A. flavus pada berbagai perlakuan sampai pengamatan 14 HSI

Berdasar pengamatan diameter pertumbuhan jamur dan bakteri dapat diketahui persentase penghambatan A. flavus yang disajikan pada Gambar 5. Pada kontrol, mulai hari ke 1 sampai 14 HSI tidak terjadi penghambatan, pertumbuhan A. flavus tidak terkendali. Penghambatan A. flavus oleh B. subtilis dimulai pada hari ke 2 hsi $33 \%$, meningkat pada hari 14 HSI 74\%. Pada perlakuan PfAf, penghambatan A. flavus oleh $P$. fluoresens hari ke 14 HSI $60 \%$. Bila dibandingkan dengan kontrol, BsAF dan menghambat A. flavus sebesar $74 \%$ sedangkan PfAF penghambatannya sebesar $60 \%$. Dengan demikian penghambatan pertumbuhan $A$. flavus oleh $B$. subtilis penghambatan lebih efektif daripada $P$. fluoresens.
Dengan hasil tersebut dapat disimpulkan bahwa baik $B$. subtilis maupun $P$. fluorescens mempunyai potensi untuk digunakan sebagai agens hayati untuk mengendalikan A. flavus. Menurut Rao (1994) B. subtilis mampu memproduksi antibiotik aterimin dan basitrasin yang sangat beracun bagi patogen.

Pseudomonas spp. kelompok fluorescens dapat menekan perkembangan penyakit tanaman dengan beberapa cara antara lain: kompetisi unsur besi $\left(\mathrm{Fe}^{3+}\right)$, kompetisi unsur karbon dan produksi antibiotik (Oka, 1993; Leong, 1986). Menurut Misaghi et al. (1982), aktivitas $P$. fluorescens dalam menghambat pertumbuhan berbagai jamur, disebabkan oleh kemampuannya untuk mengambil unsur besi $\left(\mathrm{Fe}^{3+}\right)$ dari media dengan membentuk kompleks besi pigmen. 


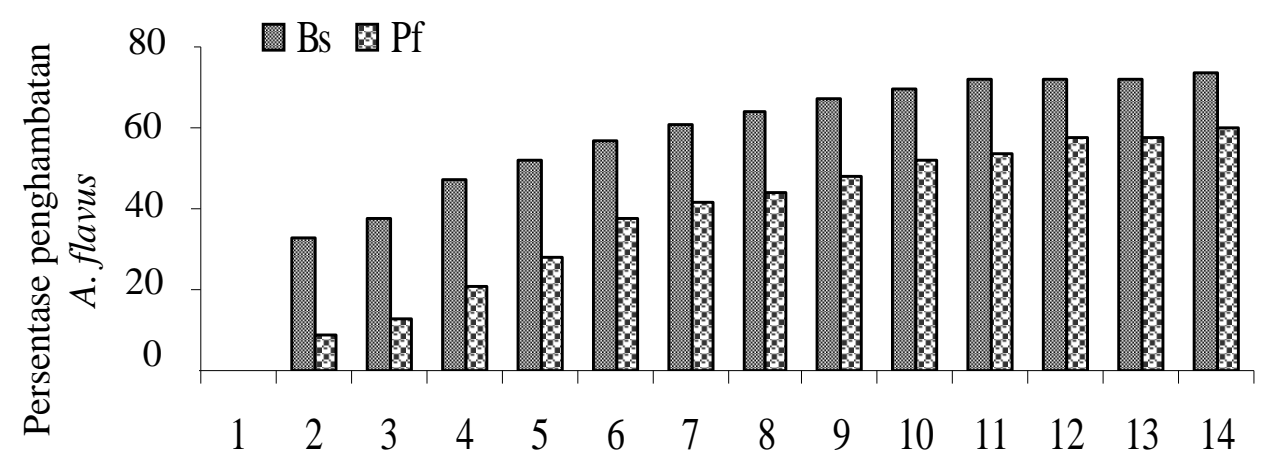

Pengamatan hari ke

Gambar 5. Grafik persentase penghambatan A. flavus pada berbagai perlakuan

Uji Penghambatan Aspergillus oleh BPF pada Fase Perkecambahan Kacang Tanah secara Hidroponik. Hasil penelitian yang meliputi persentase penyakit sebelum tumbuh, persentase penyakit sesudah tumbuh, berat basah akar, berat kering akar dan total panjang akar menunjukkan bahwa setiap perlakuan memberikan hasil yang mendukung hasil uji in vitro.

Tabel 1 menunjukkan pengaruh cara pemberian BPF terhadap berat basah akar. Nilai tertinggi diperoleh pada perlakuan Desikator Supernatan (DS) yaitu sebesar $28,3 \mathrm{~g}$, hal ini diduga karena pertumbuhan dan fungsi akar terjadi secara sempurna sehingga dapat menyerap dan menyimpan unsur hara secara optimal. Berat basah akar merupakan hasil pertumbuhan yang optimal suatu tanaman, tidak terlepas dari semua faktor yang mendukungnya seperti media yang mengandung unsur hara dan cahaya. Dibandingkan dengan perlakuan kertas langsung (KL), DS dapat meningkatkan berat basah akar sebesar $29 \%$.

Secara fisiologis, akar merupakan organ penyerap yang mengambil air dan garam-garam mineral dari media tumbuh, selain itu akar mempunyai kemampuan menyimpan bahan makanan yang berasal dari daun (Heddy, 1990). Hara diserap tanaman dalam bentuk ion bermuatan positif $\left(\mathrm{NH}_{4}^{+}, \mathrm{K}^{+}, \mathrm{Ca}^{++}, \mathrm{Mg}^{++}\right)$dan bermuatan negatif $\left(\mathrm{NO}_{3}^{-}, \mathrm{HP}_{4}=\mathrm{Cl}^{-}\right)$. Fase pertama hara tanaman berpindah tempat dari medium tumbuh kepermukaan akar tanaman. Setelah sampai di permukaan akar (bulu akar), masuk ke dalam akar yang kemudian ditranslokasikan ke organ tanaman yang lain (Rosmarkam \& Yuwono, 2006).
Banyak hal yang mempengaruhi infeksi patogen pada tanaman budidaya secara hidroponik di antaranya adalah sumber inokulum yang mungkin terdapat pada media tumbuh, tumbuhan hidup yang terinfeksi, larutan yang kurang steril, benih atau materi vegetatif bakal tanaman yang terinfeksi, tempat/bejana yang terkontaminasi dan agen hidup lain yang dapat membawa patogen (Sinaga, 2003).

Interaksi antara macam BPF dan cara pemberian BPF menunjukkan bahwa berat kering akar tertinggi diperoleh dari perlakuan BsDS yaitu sebesar 24,1 g (Tabel2). Dari Tabel 2 terlihat bahwa bila dibandingkan dengan perlakuan KDS, perlakuan BsDS dapat meningkatkan berat kering akar sebesar 107,2\% sedang dengan perlakuan PfDS dapat meningkatkan berat kering akar sebesar 99\%. Hal ini diduga karena larutan Hougland mengandung senyawa pengikat unsur $\mathrm{P}$, dengan adanya aplikasi $B$. subtilis strain $S K$ yang mempunyai kemampuan melarutkan $\mathrm{P}, \mathrm{P}$ dalam larutan Hougland menjadi tersedia bagi tanaman, sehingga $\mathrm{P}$ dapat diserap akar lebih cepat yang mengakibatkan jumlah biomassa akar semakin besar.

Dalam pertumbuhannya, akar membutuhkan unsur esensiil seperti P. Senyawa dalam media yang mengandung unsur $\mathrm{P}$ dapat dihidrolisis oleh mikrobia. Kemampuan mikrobia melakukan hidrolisis senyawa itu dengan mengeluarkan enzim sehingga $P$ lepas sebagai $P$ anorganik yang dilepaskan ke dalam larutan. Di dalam tanah, khususnya di sekitar perakaran umumnya ditemukan jasad renik yang mempunyai kemampuan untuk melarutkan P-tidak terlarut menjadi P-larut yang akhirnya dapat dimanfaatkan oleh tanaman. 
Tabel 3 menunjukkan nilai total panjang akar. Nilai tertinggi diperoleh pada perlakuan B. subtilis strain $S K$ pada desikator supernatan dengan larutan air dan Hoagland (BsDSA dan BsDSH) dan pada perlakuan $P$. fluorescens pada desikator supernatan dengan larutan Hoagland (PfDSH). Hasil tersebut menunjukkan bahwa perlakuan BPF dengan DS dan H menghasilkan pengaruh positif terhadap pertumbuhan akar. Menurut Lakitan (2004), faktor yang mempengaruhi pola penyebaran akar diantaranya adalah penghalang mekanis, suhu tanah/larutan, aerasi, ketersediaan air dan ketersediaan unsur hara.

Hasil analisa P total saat tanam dan 14 HST pada masing-masing perlakuan menunjukkan konsentrasi $\mathrm{P}$ total perlakuan kontrol pada kertas langsung dengan Air (KKLA) saat tanam adalah 0 ppm tetapi setelah 14 HST konsentrasi $\mathrm{P}$ total mengalami penambahan sebesar 0,1 ppm. Hal yang sama terjadi pada kontrol Desikator supernatan dengan Air (KDSA). Sedangkan pada perlakuan penggunaan $B$. subtilis strain $S K$ pada Desikator dengan larutan Hougland (BsDSH) konsentrasi P total saat tanam sebesar 62,0 ppm dan saat 14 HST sebesar 47,5 ppm, mengalami penurunan sebesar 14,5 ppm. Pada perlakuan P. fluorescens pada
Desikator supernatan dengan larutan Hougland (PfDSH) konsentrasi P total saat tanam sebesar 112,7 ppm dan saat 14 HST sebesar 93,0 ppm, mengalami penurunan sebesar 19,7 ppm (Tabel 4).

Konsentrasi $\mathrm{P}$ total mengalami penambahan atau penurunan kemungkinan dipengaruhi oleh aktivitas mikroba dalam larutan dan juga dipengaruhi oleh aktivitas yang dilakukan oleh tanaman. Kenaikan konsentrasi P total pada kontrol saat 14 HST diduga diperoleh dari eksudat akar kecambah dan juga berasal dari aplikasi A. flavus. Penurunan konsentrasi $\mathrm{P}$ total saat 14 HST oleh B. subtilis strain $S K$ lebih kecil dibandingkan penurunan konsentrasi $\mathrm{P}$ total oleh $P$. fluorescens. Keterkaitan antara perubahan $\mathrm{pH}$ medium setelah pertumbuhan dengan jumlah fosfat yang dilarutkan belum diketahui (Rao, 1994).

Fosfat dapat menjadi tersedia untuk perakaran melalui sekresi asam organik mikroorganisme. Pelarutan fosfat oleh mikroorganisme juga tergantung pada $\mathrm{pH}$ larutan. Pada $\mathrm{pH}$ netral dan basa yang memiliki kandungan kalsium yang tinggi, terjadi pengendapan kalsium fosfat, sehingga mikroorganisme mampu melarutkan fosfat dan mengubah menjadi tersedia bagi tanaman.

Tabel 1. Pengaruh perlakuan cara pemberian BPF terhadap berat basah akar

\begin{tabular}{cc}
\hline Perlakuan cara pemberian BPF (B) & Berat basah akar (g) 14 HST \\
\hline KL & $7,1 \mathrm{~b}$ \\
DS & $28,3 \mathrm{a}$ \\
\hline
\end{tabular}

Keterangan: Huruf yang sama menunjukkan tidak berbeda nyata pada uji jarak Duncan taraf $5 \%$.

Tabel 2. Pengaruh macam BPF dan cara pemberian BPF terhadap berat kering akar

\begin{tabular}{ccr}
\hline \multicolumn{2}{c}{ Perlakuan } & Berat kering akar (g) 14 HST \\
\hline Macam BPF & Cara pemberian BPF & $3,4 \mathrm{c}$ \\
K & KL & $11,6 \mathrm{~b}$ \\
& DS & $3,6 \mathrm{c}$ \\
Bs & KL & $24,1 \mathrm{a}$ \\
& DS & $2,9 \mathrm{c}$ \\
Pf & KL & $23,2 \mathrm{a}$ \\
\hline
\end{tabular}

Keterangan: Huruf yang sama menunjukkan tidak berbeda nyata pada uji jarak Duncan $5 \%$. 
Tabel 3. Pengaruh macam BPF, cara pemberian BPF dan macam larutan terhadap total panjang akar

\begin{tabular}{|c|c|c|c|}
\hline \multicolumn{3}{|c|}{ Perlakuan } & \multirow{2}{*}{$\begin{array}{c}\text { Total panjang akar }(\mathrm{cm}) \\
14 \mathrm{HST}\end{array}$} \\
\hline Macam BPF & Cara pemberian BPF & Macam larutan & \\
\hline \multirow{4}{*}{$\mathrm{K}$} & \multirow{2}{*}{ KL } & A & $7,1 \mathrm{~b}$ \\
\hline & & $\mathrm{H}$ & $7,0 \mathrm{~b}$ \\
\hline & \multirow{2}{*}{ DS } & A & $3,2 \mathrm{c}$ \\
\hline & & $\mathrm{H}$ & $6,4 \mathrm{~b}$ \\
\hline \multirow{4}{*}{ Bs } & \multirow{2}{*}{$\mathrm{KL}$} & A & $4,9 \mathrm{c}$ \\
\hline & & $\mathrm{H}$ & $5,3 \mathrm{c}$ \\
\hline & \multirow{2}{*}{ DS } & A & 9,9 a \\
\hline & & $\mathrm{H}$ & $9,6 \mathrm{a}$ \\
\hline \multirow{4}{*}{$\mathrm{Pf}$} & \multirow{2}{*}{$\mathrm{KL}$} & A & $4,7 \mathrm{c}$ \\
\hline & & $\mathrm{H}$ & $4,8 \mathrm{c}$ \\
\hline & \multirow{2}{*}{ DS } & A & $7,4 \mathrm{~b}$ \\
\hline & & $\mathrm{H}$ & $9,1 \mathrm{a}$ \\
\hline
\end{tabular}

Keterangan: Huruf yang sama menunjukkan tidak berbeda nyata pada uji jarak Duncan 5\%.

Tabel 4. Hasil analisa pH dan konsentrasi P total pada media pertumbuhan pada saat tanam (0 HST) dan 14 HST

\begin{tabular}{lrrrr}
\hline \multirow{2}{*}{\multicolumn{1}{c}{ Perlakuan }} & \multicolumn{2}{c}{ 0 HST } & \multicolumn{2}{c}{ 14 HST } \\
\cline { 2 - 5 } & $\mathrm{pH}$ & $\mathrm{P}(\mathrm{ppm})$ & $\mathrm{pH}$ & $\mathrm{P}(\mathrm{ppm})$ \\
\hline Kontrol, Kertas Langsung, Air (KKLA) & 6,5 & 0 & 6,7 & 0,1 \\
Kontrol, Kertas Langsung, Hougland (KKLH) & 7,9 & 209,1 & 8,0 & 223,1 \\
Kontrol, Desikator Supernatan, Air (KDSA) & 6,5 & 0 & 6,7 & 0,1 \\
Kontrol, Desikator Supernatan, Hougland (KDSH) & 8,0 & 217,1 & 8,4 & 230,4 \\
B. subtilis, kertas Langsung, Air (BsKLA) & 7,8 & 97,8 & 8,0 & 80,5 \\
B. subtilis, kertas Langsung, Hougland (BsKLH) & 7,8 & 85,6 & 8,0 & 68,6 \\
B. subtilis, Desikator Supernatan, Air (BsDSA) & 7,9 & 68,0 & 8,4 & 51,1 \\
B. subtilis, Desikator Supernatan, Hougland (BsDSH) & 7,9 & 62,0 & 8,7 & 47,5 \\
P. fluorescens, Kertas Langsung, Air (PfKLA) & 8,1 & 122,2 & 7,9 & 99,5 \\
P. fluorescens, Kertas Langsung, Hougland (PfKLH) & 8,0 & 127,3 & 7,7 & 105,3 \\
P. fluorescens, Desikator Supernatan, Air (PfDSA) & 8,0 & 175,3 & 7,5 & 155,3 \\
P. fluorescens, Desikator Supernatan, Hougland (PfDSH) & 8,1 & 112,7 & 7,3 & 93,0 \\
\hline
\end{tabular}

Keterangan: P total dianalisis dengan metode Olsen (Maxwell, 1968). 


\section{SIMPULAN}

Berdasarkan hasil dan analisis penelitian dapat disimpulkan:

1. Secara in vitro, B. subtilis strain SK lebih efektif menghambat pertumbuhan A. flavus dibandingkan P. fluorescens strain GM. Bacillus subtilis strain SK dapat menghambat A. flavus sebesar 74,4\% sedangkan $P$. fluorescens strain GM penghambatannya sebesar $59,8 \%$, jika dibandingkan dengan kontrol.

2. Perlakuan B. subtilis dan Desikator Supernatan dapat meningkatkan berat kering akar sebesar 107,2\%. Sedangkan perlakuan P. fluorescens dan Desikator Supernatan dapat meningkatkan berat kering akar sebesar 99\%, jika dibandingkan dengan perlakukan Kontrol dan Desikator Supernatan.

3. B. subtilis strain SK lebih efektif melarutkan fosfat dibandingkan P. fluorescens strain GM.

\section{DAFTAR PUSTAKA}

Adisarwanto T. 2000. Meningkatkan Produksi Kacang Tanah di Lahan Sawah \& Lahan Kering. Penebar Swadaya. Jakarta.

Asis R, Barrionuevo DL, Giorda LM, Nores ML \& Aldao MA. 2005. Aflatoxin production in six peanut (Arachis hypogaea L.) genotypes infected with Aspergillus flavus and Aspergillus parasiticus, isolated from peanut production areas of Cordoba, Argentina. J. Agric. Food Chem. 53(23): 92749280.

Bryden WL. 1999. Aflatoxin and reduction in contaminated commodities. Pp.18-20 In: Dietzgen RG, eds. ACIAR Proceeding: Eliminator of Aflatoxin Contamination in Peanut.

Cotty PJ \& Jaime-Garcia R. 2007. Influences of climate on aflatoxin producing fungi and aflatoxin contamination. Int. J. Food Microbiol. 119(12): 109-115.
Guzmán de Peña D. 2007. Exposure to aflatoxin B1 in experimental animals and its public health significance. Salud Publica Mex. 49(3): 227235.

Hansen RB \& Norman KL. 1999. Economic Importance of aflatoxin to the Australian peanut industry. Pp. 7-9 In: Dietzgen RG, eds. Aciar Proceeding: Elimination of Aflatoxin Contamination in Peanut.

Heddy S. 1990. Biologi Pertanian. Rajawali. Jakarta.

Lakitan B. 2004. Dasar-Dasar Fisiologi Tumbuhan. PT. Raja Gravindo Persada. Jakarta.

Leong J. 1986. Siderophore: their biochemistry and posible role in the biocontrol of plant pathogens. Annu. Rev. Phytopathology 5: 24-25.

Maxwell JA. 1968. Phosphorus. Pp. 187-194 In: Elving PJ \& Kiothoff IM, eds. Chemical analyses- $a$ series of monographs on analytical chemistry and its applications, vol. 27. J. Wiley \& Sons, Inc., New York.

Misaghi IJ, Stowell LJ, Grogan RG \& Spearman LC. 1982. Fungistatic Activity of Water Soluble fluorescens Pigments of fluorescent Pseudomonads. Phytopathology 1: 72-87.

Oka IN. 1993. Pengantar Epidemologi Penyakit Tanaman. Gadjah Mada University Press. Yogyakarta.

Rao SNS. 1994. Mikroorganisme Tanah dan Pertumbuhan Tanaman. UI-Press. Jakarta.

Rodriguez H \& Fraga R. 1999. Phosphate solubilizing bacteria and their role in plant growth promotion. Biotechnol Adv. 17: 319-339. 
Rosmarkam A \& Yuwono NW. 2006. Ilmu Kesuburan Tanah. Kanisius. Yogyakarta.

Sastrahidayat. 1987. Petunjuk Penggunaan Pestisida. Rineka Cipta. Jakarta.

Shweta, Bhatia, Maheshwari DK, Dubey RC, Azora DS, Bajpai VK \& Kang SC. 2008. Beneficial effects of fluorescent Pseudomonads on seed germination, growth promotion, and suppression of charcoal rot in groundnut (Arachis hypogea L.). J. Microbiol. Biotechnol. 8(9): 1578-1583.
Sinaga MS. 2003. Dasar-dasar Ilmu Penyakit Tumbuhan. Penebar Swadaya. Jakarta.

Sudjadi S, Mahmud M, Darmadjati DS, Hidayat A, Widowati S \& Widiati A. 1999. Aflatoxin research in Indonesia. Pp. 23-25 In: Dietzgen RG, eds. ACIAR Proceeding: Elimination of Aflatoxin Contamination in Peanut.

Supartini V. 1997. Dampak Serangan Jamur Aspergillus flavus terhadap Kandungan Aflatoksin pada Kacang Tanah dalam Beberapa Jenis Kemasan. Laporan Penelitian. Lemlit UNEJ, Jember. 